4

5 7

\title{
Treatment Status and Use of Psychoactive Substances in Deceased Drug Users
}

\section{Treatment Status in Deceased Drug Users}

Line Kruckow $^{1 *}$, Christian Tjagvad ${ }^{2}$, Thomas Clausen ${ }^{2}$, Kristian Linnet ${ }^{1}$, Jytte Banner ${ }^{1}$

${ }^{1}$ Department of Forensic Medicine, University of Copenhagen, Copenhagen, Denmark

${ }^{2}$ Norwegian Centre for Addiction Research [SERAF], University of Oslo, Oslo, Norway

*Corresponding Author

Line Kruckow

Department of Forensic Medicine

University of Copenhagen

Frederik V’s Vej 11

2100 København Ø, Denmark

Tel.: +45 35331352

E-mail: line.kruckow@sund.ku.dk

Keywords: Drug users, mortality, substance abuse treatment centers, prescription drugs 
3 Background: Studies on drug use are limited by the study populations available, which usually

$4 \quad$ only include drug users in treatment settings. Therefore, the knowledge base is limited on drug

5 users not entering treatment for drug use disorder (DUD). Using registers from departments of

6 forensic medicine enables research on decedents with DUD, irrespective of treatment status.

7 Objectives: The aim of this study is to characterise and compare drug users not receiving treatment

8 and drug users receiving treatment, in relation to cause of death, toxicological findings and use of

9 non-prescribed medication.

Methods: Retrospective register-based study on deceased drug users with supplemental data from the Registry of Drug Abusers Undergoing Treatment and the Register of Medicinal Product Statistics in two observation periods: 2001-2002 and 2011-2012.

Results: Two thirds of the population were not receiving treatment at the time of death in both observation periods. Drug users receiving treatment were more likely to die from accidental poisonings than drug users not receiving treatment. There was no difference in mean age at the time of death between the two groups, and both groups were older in the second observation period. There was no difference in toxicological findings according to treatment status and the two groups did not differ in the presence of non-prescribed medication found in the blood at the time of death. Discussion/Conclusions: The proportion of drug users that received treatment prior to death has not increased and deceased drug users are mostly not in treatment for their drug use at the time of death.

Keywords: Drug users, mortality, substance abuse treatment centers, prescription drugs 
Introduction

Prevention of drug-related or drug-induced premature mortality relies on identification of the population at risk. Drug users receiving treatment are readily available for research and societal efforts at prevention, whereas drug users not receiving treatment are less so. Therefore, it is important to identify and examine drug users who for various reasons do not receive treatment for their drug use to illuminate an area that may need increased awareness in order to improve preventive efforts.

Most studies on drug use, use of prescription medication and mortality in individuals with drug use disorder (DUD) recruit their study populations from treatment centres or registers of drug users in treatment [1-6]. Limited data exist for individuals with drug use not receiving treatment $[7,8]$. Few studies include drug users receiving treatment and those not receiving treatment (mixed treatment status) $[9,10]$. This includes official reports in Denmark as The Danish National Health Agency only counts individuals with DUD as those with a more prolonged and detrimental use of illicit psychoactive substances and not those who have experimental behaviour [11]

Individuals who use drugs have lower life expectancy than the general population $[6,12,13]$. In Denmark, municipalities offer treatment for drug use under the National Board of Social Service. Every individual has the right to receive treatment within 14 days of requesting it. Treatment is not organised as part of the healthcare system, but may be delegated to individual general practitioners within the primary healthcare system. Drug users are only treated in hospital or specialist settings during acute intoxications. 
51 In Danish OMT regimens, buprenorphine is marked as drug of first choice [14], but methadone is most commonly prescribed [11]. Both medications have addictive potential and are commonly used by individuals with DUD outside of treatment settings, leading to increased mortality [15]. Methadone and buprenorphine as part of Opioid Maintenance Treatment (OMT) lower the risk of very premature drug-related death among individuals with opioid use disorder [16]. Between 2000 and 2010 the focus of OMT in Denmark shifted towards a more user-oriented approach with increased medicalisation and an overall health orientation. This liberal approach reduced control mechanisms in methadone treatment such as supervised intake, urine tests and sanctions for not fulfilling administrative demands and instead increased the access for many users as well as offered the possibility of take-home doses and dosage above the recommendation $[17,18]$. Liberal prescription practices of OMT medication, however, may elevate the risk of overdose death while in treatment, due to low safety levels within the program, such as lack of supervised intake of medication [3]. Liberal or inappropriate prescription of very high OMT doses or co-prescription of benzodiazepines [3,19], methylphenidate and hypnotics may lead to increased non-prescribed access among drug users outside of treatment settings and thus a higher risk of death [20-25].

One way to extend the knowledge base on drug users not seeking treatment is through the registers of forensic medicine departments in Denmark. Every death brought in for legal inquest, where psychoactive substances (excluding alcohol) are suspected of being involved in the cause of death, undergoes mandatory autopsy and toxicological screening [26]. The registers are not 100\% complete, as not all deceased drug users are autopsied after death, if the attending physician does not perceive the death as drug-related [27-29]. The forensic registers remain, however, one of a 
74 limited number of sources on drug users not receiving treatment, with fairly high coverage of

8 deceased drug users in treatment and outside of treatment at time of death.

To date there is limited knowledge about treatment status in relation to cause of death, the toxicological profile of psychoactive substances found in the blood at the time of death and the use of non-prescribed medication prior to death.

The aim of this study is to identify and characterise drug users not receiving treatment for DUD and compare them to drug users receiving treatment for DUD at the time of death. Comparisons will be made on cause of death, toxicological findings of psychoactive substances and use of nonprescribed medication. We aim to explore if there are temporal trends based on autopsy of individuals with positive toxicology in the years 2001-2002 and 2011-2012.

\section{Materials and methods}

Study population

All drug users autopsied at the Department of Forensic Medicine, Section of Forensic Pathology (Copenhagen, Denmark), in the years 2001 ( $n=135), 2002$ ( $n=116), 2011$ ( $n=173)$ and 2012 $(n=136)$. The department covers the eastern part of Denmark, encompassing approximately 2.5 million inhabitants and comprising nearly $50 \%$ of the total population. Decedents were included as drug users based on either knowledge of drug use prior to death through police reports or through identification of psychoactive substances or substitution medication found in the toxicological screening. 
From the original 560 drug users, 36 were excluded due to invalid Danish Personal Identification numbers or the cases were non-Danish citizens. For the final analysis, 240 drug users were included from the years 2001-2002, and 284 from the years 2011-2012.

Toxicology reports were assessed, and all occurrences of the following prescription medications were registered for analysis (Table 1). For ease of registration and because several drug metabolites may also be marketed as medication in themselves, medication within the following Anatomical Therapeutic Chemical (ATC) classification system levels has been grouped together with the exception of benzodiazepines and morphine.

Table 1.

The study population was linked to two Danish health registries: the Registry of Drug Abusers Undergoing Treatment (Stofmisbrugere i Behandling - SIB) [30,31] and the Register of Medicinal Product Statistics (Lægemiddelstatistikregistret - LSR) [32]. All data entries for each drug user were acquired up to two years prior to autopsy and linked through the Danish Personal Identification number. The autopsy date has been used as the reference date for the analyses.

The SIB register encompasses all individuals receiving treatment for drug use in Denmark and information on OMT prescribed, including by a general practitioner. The LSR includes information on individual prescription medication dispensed by all Danish pharmacies. The data collected in this study include generic names, ATC codes for the medications listed in Table 1, and the date the medication was dispensed. All dispensed medication entries up to two months ( $<56$ days) before the 
autopsy were included, encompassing most prescriptions with a one-month prescription interval and accounting for the uncertain time period between the actual date of death and autopsy date.

The SIB and LSR dataset formed the basis for dividing the study population into four subpopulations:

Group 1: Drug users receiving treatment 2001-2002

Group 2: Drug users not receiving treatment 2001-2002

Group 3: Drug users receiving treatment 2011-2012

Group 4: Drug users not receiving treatment 2011-2012.

Drug users receiving treatment: registered in SIB irrespective of contact type or length at the time of death or autopsy. Contacts in SIB registered as concluded because of the recipient's death or for other reasons at or after the autopsy date were included. Contacts registered as concluded up to one week prior to the autopsy date were individually assessed using information from the police report on the date the individual was last seen alive. Drug users not registered in SIB but who were registered as having received OMT medication including Methadone from a pharmacy $<56$ days prior to autopsy were included as in treatment at the time of death.

Drug users not receiving treatment were defined as all other individuals included.

\section{Identifying cause of death}

All modes and manners of deaths were registered from the forensic autopsy reports. All causes of death were coded according to the International Classification of Disease $10^{\text {th }}$ edition (ICD-10) [33]. 
144 Cases of death from fatal combination poisoning were encoded as poisoning by the drug or 145 medication believed to be the primary agent responsible for death as estimated by the Section of 146 Forensic Chemistry.

148 Causes of deaths were divided into four groups:

1. Somatic causes of deaths. Includes all somatic diseases as well as any death where the underlying cause of death is a medical condition that can be caused by long-term drug use.

2. Accidental poisonings. Includes all deaths due to acute (accidental) poisoning by illicit substances as well as all types of licit medication.

3. Trauma. Includes all homicides, suicides (incl. intentional poisonings) and fatal accidents without illicit and/or licit drugs being involved, or where illicit/licit substances had a contributory role but were not the underlying cause of death.

4. Unknown cause of death.

Statistical analysis

Statistical analysis was performed using IBM SPSS Statistics, version 24 for Windows. Chi-square, independent T-test and Mann-Whitney U test and one-way ANOVA were used to test for differences between groups. Significance level was set to $p<0.05$.

\section{Results}

The 2001-2002 period included 240 individuals, 284 individuals were in the 2011-2012 period. 
169 There were no significant changes between the two observation periods concerning the grouped

170 categories of death: somatic death, accidental poisonings or trauma. There was a decrease in deaths

171 where a definite cause of death could not be determined in 2011-2012. Two thirds of the population

172 in both observation periods died from accidental opioid poisoning, but the distribution between

173 heroin/morphine and methadone changed between 2001-2002 and 2011-2012. In the first

174 observation period 28.8\% died from methadone, increasing to 56.0\% in 2011-2012.

175

176 Around one third of the study population were identified as drug users receiving treatment at the 177 time of death, similar in both observation periods.

179 Table 2.

Secondly, we assessed the proportion of drug users receiving treatment at the time of death in relation to the estimated population at risk. According to the Danish Health Authority, there were 10,125 drug users receiving treatment in 2001 and 16,200 in 2011 [34,35]. No absolute numbers have been published from 2002 or 2012. Correlating these numbers to our results we find that 0.89\% of the population in treatment died in 2001 and $0.54 \%$ died in 2011.

187 Table 3 explores the toxicological screening results in relation to treatment status. In both observation periods, the only psychoactive substance differing significantly between drug users receiving treatment and those not receiving treatment was methadone ( $p=0.000$ in 2001-2002 and 2011-2012). 
We estimated the proportions of major drug groups such as antipsychotics and antidepressants that were not prescribed prior to death by subtracting dispensed medication from the results of the toxicological screening for each individual drug user. From 2001-2002 to 2011-2012 the proportions of non-prescribed psychostimulants $(0-2.1 \%, p=0.02)$, benzodiazepines $(16.7-34.5 \%$, $p=0.00)$, and methadone (36.3-53.2\%, $p=0.00)$ all increased. Non-prescribed opioids (excl. morphine) decreased $(27.1-7.4 \%, p=0.00)$. The remaining non-prescribed drug groups did not differ significantly across the two observation periods.

Illicit methadone was significantly more often present in the toxicological screening among drug users not receiving treatment in both observation periods. The remaining illicit psychoactive substances identified post-mortem across groups were not significantly different in either observation period.

Table 3.

* Indicates significant difference

**Buprenorphine also includes combinations with buprenorphine (N07BC51).

Table 4 examines the relationship between treatment status and cause of death. Concerning age at the time of death, in both observation periods there was no significant difference between drug users receiving treatment compared to those not receiving treatment. A one-way ANOVA showed a significant increase in mean age from 2001-2002 to 2011-2012 for both groups (drug users receiving treatment: 40.4 to 44.7 years, $p=0.023$, 95\% CI: $0.42-8.22$ and drug users not receiving treatment: 38.2 to 42.0 years, $p=0.003,95 \% \mathrm{CI}: 1.04-6.70)$. 
217 In 2011-2012 a larger proportion of the drug users receiving treatment died from accidental 218 poisoning than drug users not receiving treatment (OR: 2.305, 95\% CI: 1.23-4.33). All other causes 219 of deaths showed no significant differences according to treatment status in either observation 220 period.

Table 4.

$224 *$ Indicates significant difference.

$225 * *$ Numbers cannot be shown as the subpopulation sizes can be identified using other tables 226 presented and they may be lower than 4 cases.

\section{Discussion/Conclusion}

Treatment status

In both observation periods, around one third of the deceased population with positive toxicology was registered in drug treatment at the time of autopsy. Therefore, two thirds of the deceased drug users were not receiving treatment at the time of death.

According to the Danish Health Agency, there was a general increase in drug users receiving treatment in Denmark from 2002 to 2013 [11]. The use of cannabis explains the majority of the increase in drug users entering treatment and the increase of people with DUD in general [11,34]. In 238 the same period, 2002-2013, the proportion of drug users receiving treatment who reported using 239 illicit opioids decreased from 62\% (approx. 2528 persons) in 2001 to 17\% (approx. 966 persons) in 
2011 whereas cannabis increased from 17\% to 63\% [34]. Of the drug users entering treatment for the first time (treatment-naïve drug users) the proportion reporting opioids as their drug of choice decreased from $17 \%$ to just $6 \%$ in 2013 [11]. These changes in the population of living drug users in treatment were not reflected in our study population.

There was no difference in age according to treatment status, but the mean age increased for both groups between the two observation periods. These findings differ from earlier studies $[9,36]$. However, these may not be comparable as these studies focused on opioid users whereas we included all drug users irrespective of their drug of choice.

\section{Cause of death}

In our study, we found that drug users receiving treatment were more likely to have died from accidental poisoning than drug users not receiving treatment. All other causes of deaths showed no significant differences according to treatment status. These findings are not consistent with other studies but may be due to difference in study populations [36] and national variations in availability of OMT as Denmark has liberal prescription practices [2,3]. It is possible that the drug users receiving treatment are more severely impacted by their DUD than those not in treatment and because of this have an overall higher risk of death due to accidental poisoning.

We do not know the primary drug used by each decedent; however, more than two thirds of the population in both observation periods died of opioid poisoning. Because of this, we suspect that the majority were primary opioid users or mixed users.

As there are no official estimates of the population of opioid users in Denmark, the population at risk is difficult to estimate. Reports by the Danish Health Agency estimate that $40 \%$ of the entire 
population of drug users were registered in treatment in 2001 [35]. The population of drug users was last estimated in 2009 [37], when the population had increased but still 40\% were registered as having received treatment in the same year.

Using the absolute treatment numbers from the 2003 and 2013 reports (that concern the years 2002 and 2012), we found that in 2002 0.89\% of the population registered in treatment was identified in our autopsy material [34,35]. In 2012 it had decreased to 0.54\% [34]. These numbers may show a decrease in risk of death while in treatment, but more likely the reduction mirrors the change in treatment cohort mentioned above with a majority being cannabis users.

The total number of deaths from opioid poisoning in Denmark was stable between the years 20022012 at around 80\% of all accidental poisonings (198 and 166 deaths respectively in the two time periods) [34]. We fear that drug users most at risk for premature mortality, opioid users, are increasingly less likely to be targeted by preventive measures as fewer are included in treatment at time of death.

\section{Toxicological findings}

In the general population between 2001 and 2012 there was an increase in prescription rates of antipsychotics, antidepressants and psychostimulants [38]. We did not find an increase in nonprescribed antipsychotics or antidepressants identified in the toxicological screening in our study population. Prescription rates of benzodiazepines decreased from 2001 to 2012 in the general population, but the presence of non-prescribed benzodiazepines in the blood at time of death increased substantially within the drug-using population. We do not know if illegal imported 
benzodiazepines increased in the same period, which may account for the increase found in this study.

Unlike other studies [21,22,24], we found a marked decrease in the presence of opioids, excluding methadone, in the blood at time of death and a marked increase of non-prescribed methadone. At the same time, methadone prescription rates increased and other opioids decreased, except for tramadol, between 2002-2012 [39]. Combining this with the liberalisation of the OMT regimens in Denmark in the same period $[17,18]$, we are concerned that the increased prescription rates of methadone are directly responsible for the increased presence in the toxicological screening of nonprescribed methadone. Clinicians should be aware of this when prescribing methadone as part of OMT and balance the need for access with the need for safety to ensure that the risk of death does not increase for those receiving or not receiving treatment.

\section{Use of non-prescribed psychoactive substances}

Treatment status did not impact the proportions of non-prescribed psychoactive substances found in the toxicological screening at autopsy except for methadone. Methadone was used to define the treatment group. These results indicate that illicit use may be equally abundant in both groups. Clinicians should be aware of this concurrent use of non-prescribed psychoactive substances, address this in treatment as a risk factor, and apply appropriate preventive measures.

\section{Limitations}

The forensic registers may be incomplete as some drug use decedents may not be routinely autopsied, due to no suspicion by police/medical professionals. The Danish Society of Forensic Medicine published a report stating that up to $40 \%$ of autopsied deceased psychiatric patients died 
from fatal overdoses, but because many psychiatric patients are not routinely autopsied in Denmark the proportion of overdose deaths may be underreported [40]. Other sources have reported inconsistencies in the numbers of substance-related deaths reported by the Danish National Health Agency [27]. For absolute rate/incidence of death the presented results may represent underestimates, but the observed associations are still perceived as valuable, and the data are an important source of information about a group of at-risk individuals otherwise not easily identified. We may have included drug users that do not fall into the category of DUD as presented by the Danish National Health Agency. These drug users may be users with experimental or irregular use of psychoactive substances only or drug users who died after first exposure to a drug. Finally, as the decedents were autopsied in two different time-periods, referral to forensic autopsy from medico-legal examination may have changed over time due to different definitions of suspected drug-related deaths that reflect current knowledge for the time by the attending physician and/or the attending police officer. This may mean that the two populations are less similar than we suspect them to be.

Because the study population is relatively numerically small, we analysed substance usage at group levels and not at individual drug level (antipsychotics in general rather than Quetiapine in particular, for example). Therefore estimates of illegal components may underestimate the proportion of non-prescribed medication if the decedent used more than one type of antipsychotic, 330 for instance.

332 A study period of 56 days prior to autopsy was deemed adequate to identify prescription medication that normally has up to four weeks prescription rates as well as account for the uncertain time 
period between death and autopsy. One occurrence of one dispension of medication within $<56$ days of autopsy was deemed sufficient explanation for presence in the toxicology screening.

Close to two thirds of the deceased drug users were not receiving treatment at the time of death in both observation periods. Defining treatment status relies on the quality of the Registry of Drug Abusers Undergoing Treatment (SIB). The two observation periods in this study are placed on opposite sides of an administrative reform in Denmark that took place in 2007. The reform led to changes in the structure of the register, including the procedures for registering entry and discharge from treatment. In both observation periods we have used the date of discharge as point of reference but are unable to validate whether these have been registered in the same matter prior and after to the reform. Treatment-receiving drug users were more likely to die from accidental poisonings than drug users not receiving treatment. This may be due to more severe DUD among those in treatment. More than two thirds died from opioid poisoning irrespective of treatment status. The proportion of non-prescribed methadone has increased as the prescription rate increased in the study population, as well as the background population.

Drug users not receiving treatment take up two thirds of the study population in both observation periods. We found few differences between drug users receiving treatment and those not receiving treatment and are thus unable to point to specific attributes in the group not receiving treatment that could have aided clinicians and social workers into recruiting this group into treatment. However, we did find a high prevalence of non-prescribed psychoactive substances among decedents including non-prescribed methadone. The liberalisation of the OMT regimens may have led to an increased prevalence of non-prescribed methadone, which may lead to increased risk of premature mortality among drug users at risk. 
Recruitment and commitment to treatment is an issue with hard-to-reach drug users. Several risk factors for dropping out of treatment have been discovered such as age, immigrant background and mental health status [41-43]. Recent studies have shown promising results applying low threshold buprenorphine treatment in outpatient settings [44,45] and the addition of assertive community treatment (ACT) may with further research lead to valuable strategies for recruitment [46].

We hypothesise that increased recruitment of opioid users into OMT with buprenorphine in addition to a more controlled access to prescription methadone may lower methadone-related mortality. and psychiatric health is needed in the future in order to reduce overdose mortality.

\section{Acknowledgement}

\section{Statement of ethics}

Ethical approval was not required for this study as the data sources are exempt from approval by the National Committee on Health Research Ethics.

\section{Disclosure statement}

379 The authors have no conflicts of interest to declare. 


\section{References}

1 Gossop M, Stewart D, Treacy S, Marsden J: A prospective study of mortality among drug misusers during a 4-year period after seeking treatment. Addiction 2002;97:39-47.

2 Tjagvad C, Clausen T, Handal M, Skurtveit S: Benzodiazepine prescription for patients in treatment for drug use disorders: a nationwide cohort study in Denmark, 2000-2010. BMC psychiatry 2016;16:168.

3 Tjagvad C, Skurtveit S, Linnet K, Andersen LV, Christoffersen DJ, Clausen T: Methadone-Related Overdose Deaths in a Liberal Opioid Maintenance Treatment Programme. European addiction research 2016;22:249-258.

$4 \quad$ Nyhlén A, Fridell M, Bäckström M, Hesse M, Krantz P: Substance abuse and psychiatric co-morbidity as predictors of premature mortality in Swedish drug abusers a prospective longitudinal study 1970 - 2006. BMC psychiatry 2011;11:122.

5 Clausen T, Waal H, Thoresen M, Gossop M: Mortality among opiate users: opioid maintenance therapy, age and causes of death. Addiction 2009;104:1356-1362.

6 Landheim AS, Bakken K, Vaglum P: Impact of comorbid psychiatric disorders on the outcome of substance abusers: a six year prospective follow-up in two Norwegian counties. BMC psychiatry 2006;6:44.

$7 \quad$ Herbeck DM, Brecht M-L, Lovinger K: Mortality, causes of death and health status among methamphetamine users. Journal of addictive diseases 2015;34:88-100.

8 Mackesy-Amiti ME, Donenberg GR, Ouellet LJ: Prevalence of psychiatric disorders among young injection drug users. Drug \& Alcohol Dependence;124:70-78.

$9 \quad$ Clausen T, Anchersen K, Waal H: Mortality prior to, during and after opioid maintenance treatment (OMT): A national prospective cross-registry study. Drug and Alcohol Dependence 2008;94:151-157.

10 Degenhardt L, Bucello C, Mathers B, Briegleb C, Ali H, Hickman M, McLaren J: Mortality among regular or dependent users of heroin and other opioids: a systematic review and meta-analysis of cohort studies. Addiction 2011;106:32-51.

11 Sundhedsstyrelsen: Narkotikasituationen i Danmark 2015 : årsrapport til det europæiske overvågningscenter for narkotika og narkotikamisbrug, EMCDDA. Kbh., 2015, pp 56 sider.

12 Degenhardt L, Whiteford HA, Ferrari AJ, Baxter AJ, Charlson FJ, Hall WD, Freedman G, Burstein R, Johns N, Engell RE, Flaxman A, Murray CJ, Vos T: Global burden of disease attributable to illicit drug use and dependence: findings from the Global Burden of Disease Study 2010. Lancet 2013;382:1564-1574.

13 Beijer U, Andreasson A, Agren G, Fugelstad A: Mortality, mental disorders and addiction: a 5-year follow-up of 82 homeless men in Stockholm. Nord J Psychiatry 2007;61:363368.

14 Sundhedsstyrelsen: Vejledning til læger, der behandler opioidafhængige patienter med substitutionsmedicin : lovkrav og anbefalinger, Sundhedsstyrelsen, 2017,

15 Simonsen KW, Edvardsen HME, Thelander G, Ojanperä I, Thordardottir S, Andersen LV, Kriikku P, Vindenes V, Christoffersen D, Delaveris GJM, Frost J: Fatal poisoning in drug addicts in the Nordic countries in 2012. Forensic Science International 2015;248:172-180. 16 Sordo L, Barrio G, Bravo MJ, Indave BI, Degenhardt L, Wiessing L, Ferri M, PastorBarriuso R: Mortality risk during and after opioid substitution treatment: systematic review and meta-analysis of cohort studies. BMJ 2017;357

17 Frank VA, Bjerge B, Houborg E: Shifts in Opioid Substitution Treatment Policy in Denmark from 2000-2011. Substance Use \& Misuse 2013;48:997-1009. 

Countries. 2010;27:581-598.

19 Leece P, Cavacuiti C, Macdonald EM, Gomes T, Kahan M, Srivastava A, Steele L, Luo J, Mamdani MM, Juurlink DN, Canadian Drug S, Effectiveness Research N: Predictors of Opioid-Related Death During Methadone Therapy. J Subst Abuse Treat 2015;57:30-35.

20 Barrau K, Thirion X, Micallef J, Chuniaud-Louche C, Bellemin B, San Marco JL: Comparison of methadone and high dosage buprenorphine users in French care centres. Addiction 2001;96:1433-1441.

21 Centers for Disease C, Prevention: Vital signs: overdoses of prescription opioid pain relievers---United States, 1999--2008. MMWR Morb Mortal Wkly Rep 2011;60:1487-1492.

22 Dart RC, Severtson SG, Bucher-Bartelson B: Trends in opioid analgesic abuse and mortality in the United States. N Engl J Med 2015;372:1573-1574.

23 Rudd RA, Aleshire N, Zibbell JE, Gladden RM: Increases in Drug and Opioid Overdose Deaths--United States, 2000-2014. MMWR Morb Mortal Wkly Rep 2016;64:1378-1382. 24 McCabe SE, Cranford JA, West BT: Trends in prescription drug abuse and dependence, co-occurrence with other substance use disorders, and treatment utilization: Results from two national surveys. Addictive Behaviors 2008;33:1297-1305.

25 Blanco C, Alderson D, Ogburn E, Grant BF, Nunes EV, Hatzenbuehler ML, Hasin DS: Changes in the prevalence of non-medical prescription drug use and drug use disorders in the United States: 1991-1992 and 2001-2002. Drug and Alcohol Dependence 2007;90:252-260.

26 Cirkulæreskrivelse om foretagelse af lovmæssig obduktion i tilfælde af dødsfald, der må antages at stå i forbindelse med misbrug af euforiserende stoffer; in Justitsministeriet (ed). Ministerialtidende, 1970, 254, 27 Årsrapport 2014 for udsatteområdet. Landsforeningen af VæreSteder.

28 Sørensen Jf, Juel K, Brønnum-Hansen H, Sundhedsstyrelsen, Statens Institut for F: Risikofaktorer og folkesundhed i Danmark. Kbh., Statens Institut for Folkesundhed, 2006.

29 Sundhedsstyrelsen. Center for F: Narkotikasituationen i Danmark : årsrapport til det europæiske overvågningscenter for narkotika og narkotikamisbrug, EMCDDA. Årgang 2006. Kbh., Center for Forebyggelse, Sundhedsstyrelsen

bestilles hos: Schultz Information, 2006.

$30 \quad$ Sundhedsdatastyrelsen: Registerdeklaration for stofmisbrugere i behandling; in Sundhedsdatastyrelsen (ed), 2016, 31 Welfare TNBoHa: Stofmisbrugsdatabasen (Register of Individuals in Treatment for Substance Use Disorders); in Welfare TNBoHa (ed). Copenhagen, The National Board of Health and Welfare, 2015,

32 Kildemoes HW, Sørensen HT, Hallas J: The Danish National Prescription Registry. Scandinavian Journal of Public Health 2011;39:38-41.

33 Organization WH: The ICD-10 classification of mental and behavioural disorders: clinical descriptions and diagnostic guidelines. World Health Organization, 1992.

34 Sundhedsstyrelsen: Narkotikasituationen i Danmark 2013 : årsrapport til det europæiske overvågningscenter for narkotika og narkotikamisbrug, EMCDDA. Kbh., 2013, pp 116 sider.

35 Sundhedsstyrelsen: Narkotikasituationen i Danmark 2003 : årsrapport til det europæiske overvågningscenter for narkotika og narkotikamisbrug, EMCDDA. København, Sundhedsstyrelsen, 2004.

36 Degenhardt L, Randall D, Hall W, Law M, Butler T, Burns L: Mortality among clients of a state-wide opioid pharmacotherapy program over 20 years: Risk factors and lives saved. Drug and Alcohol Dependence 2009;105:9-15. 
$47537 \quad$ Sundhedsstyrelsen: Narkotikasituationen i Danmark : nationale data. Årgang 2017,

476 Sundhedsstyrelsen, 2017,

$47738 \quad$ MEDSTAT, Danish Health Data Authority,

$478 \quad 39 \quad$ Sundhedsstyrelsen: Forbrug af tramadol stiger, 2015,

$47940 \quad$ Sundhedsstyrelsen - Obduktioner giver ikke svar: Dagens Medicin, 2010,

$48041 \quad$ Brorson HH, Ajo Arnevik E, Rand-Hendriksen K, Duckert F: Drop-out from addiction 481 treatment: A systematic review of risk factors. Clinical Psychology Review 2013;33:1010-1024.

$48242 \quad$ Nordt C, Wiessing L, Kuijpers W, Wisselink J, Espelt A, Brugal MT, Mravčik V,

483 Nechanská B, Seifritz E, Herdener M: Long-Term Opioid Agonist Treatment Participation after

484 First Treatment Entry is Similar across 4 European Regions but Lower in Non-Nationals. European 485 addiction research 2018:173-183.

$48643 \quad$ Andersson HW, Steinsbekk A, Walderhaug E, Otterholt E, Nordfjærn T: Predictors of 487 Dropout From Inpatient Substance Use Treatment: A Prospective Cohort Study. Subst Abuse 488 2018;12:1178221818760551-1178221818760551.

$48944 \quad$ Bhatraju EP, Grossman E, Tofighi B, McNeely J, DiRocco D, Flannery M, Garment 490 A, Goldfeld K, Gourevitch MN, Lee JD: Public sector low threshold office-based buprenorphine 491 treatment: outcomes at year 7. Addict Sci Clin Pract 2017;12:7-7.

$49245 \quad$ Henriksen K, Jacobsen JA, Henriksen EM, Gomes L, Waal H, Krajci P: The LASSO 493 Program in Oslo: Harm Reduction Using Buprenorphine-Naloxone (Suboxone ${ }^{\circledR}$ ) in a Low 494 Threshold Setting. European addiction research 2018;24:286-292.

$49546 \quad$ Penzenstadler L, Soares C, Anci E, Molodynski A, Khazaal Y: Effect of Assertive 496 Community Treatment for Patients with Substance Use Disorder: A Systematic Review. European 497 addiction research 2019;25:56-67. 
Table 1: ATC codes included in the analysis

N Nervous system

\begin{tabular}{|c|c|}
\hline N02A & Opioids \\
\hline N02AA01 & Morphine \\
\hline N03 & Anti-epileptics, excluding N03AE01 \\
\hline N05A & Antipsychotics \\
\hline N05B & Anxiolytics, excluding benzodiazepines \\
\hline N05C & $\begin{array}{l}\text { Hypnotics and sedatives, excluding } \\
\text { benzodiazepines }\end{array}$ \\
\hline $\begin{array}{l}\text { N03AE01, N05BA01, } \\
\text { N05BA02, N05BA04, } \\
\text { N05BA06, N05BA08, } \\
\text { N05BA09, N05BA12, } \\
\text { N05CD01, N05CD02, } \\
\text { N05CD03, N05CD04, } \\
\text { N05CD05, N05CD08 }\end{array}$ & Benzodiazepines \\
\hline N06A & Antidepressants \\
\hline N06B & $\begin{array}{l}\text { Psychostimulants, agents used for attention deficit/ } \\
\text { hyperactivity disorder (ADHD) and nootropics }\end{array}$ \\
\hline \multirow{4}{*}{$\begin{array}{l}\text { N07B } \\
\text { N07BB01, -03, -05 } \\
\text { N07BC01, N07BC51 } \\
\text { N07BC02 }\end{array}$} & Drugs used in addictive disorders \\
\hline & Disulfiram \\
\hline & Buprenorphine and combinations \\
\hline & Methadone \\
\hline
\end{tabular}




\begin{tabular}{|c|c|c|c|c|}
\hline \multicolumn{5}{|c|}{ Table 2: General characteristics of the two study populations by observation period } \\
\hline & & $2001-2002$ & $2011-2012$ & \\
\hline \multicolumn{2}{|l|}{ Number } & 240 & 284 & \\
\hline \multicolumn{2}{|c|}{ Mean age (years) } & 39.0 & 42.9 & $p=0.000 *$ \\
\hline \multicolumn{5}{|c|}{ Gender } \\
\hline \multicolumn{2}{|l|}{ Male } & $84.6 \%(203)$ & $76.4 \%(217)$ & $p=0.02 *$ \\
\hline \multicolumn{2}{|l|}{ Female } & $15.4 \%(37)$ & $23.6 \%(67)$ & \\
\hline \multicolumn{2}{|c|}{$\begin{array}{l}\text { Deceased drug users receiving treatment at } \\
\text { the time of death }\end{array}$} & $37.9 \%(91)$ & $31.0 \%(88)$ & $p=0.096$ \\
\hline \multicolumn{5}{|c|}{ Cause of death } \\
\hline \multicolumn{2}{|l|}{ Somatic: } & $10.8 \%(26)$ & $13.4 \%(38)$ & $p=0.375$ \\
\hline A00-B99 & Infectious/parasitic & - & $<1.4 \%(<4)$ & \\
\hline C00-D48 & Cancers & $<1.7 \%(<4)$ & - & \\
\hline E00-E90 & Endocrine & $<1.7 \%(<4)$ & $1.4 \%(4)$ & \\
\hline F00-F99 & Mental and behavioural & - & - & \\
\hline G00-G99 & Nervous system & - & - & \\
\hline I00-I99 & Circulatory system & $5.0 \%(12)$ & $6.0 \%(17)$ & \\
\hline J00-J99 & Respiratory system & $2.9 \%(7)$ & $3.2 \%(9)$ & \\
\hline K00-K93 & Digestive system & $<1.7 \%(<4)$ & $<1.4 \%(<4)$ & \\
\hline L00-L99 & Skin and subcutaneous & - & - & \\
\hline M00-M99 & $\begin{array}{l}\text { tissue } \\
\text { Musculoskeletal system and } \\
\text { connective tissue }\end{array}$ & - & - & \\
\hline $\begin{array}{r}\text { Accidental } \\
\text { Poisoning }\end{array}$ & $\begin{array}{l}\text { oisonings: } \\
\text { ue to }\end{array}$ & $70.8 \%(170)$ & $75.7 \%(215)$ & $p=0.667$ \\
\hline Methador & & $28.8 \%(69)$ & 56\% (159) & \\
\hline Morphine & eroin & $38.3 \%(92)$ & $9.5 \%(27)$ & \\
\hline Antipsycl & tics & $<1.7 \%(<4)$ & $<1.4 \%(<4)$ & \\
\hline Antidepre & ants & - & $<1.4 \%(<4)$ & \\
\hline Anti-epile & tics & - & $<1.4 \%(<4)$ & \\
\hline Benzodia & pines & $<1.7 \%(<4)$ & $<1.4 \%(<4)$ & \\
\hline Alcohol & & $2.1 \%(5)$ & $1.4 \%(4)$ & \\
\hline Illegal psy & hoactive substances & $<1.7 \%(<4)$ & $2.8 \%(8)$ & \\
\hline Trauma: & & $9.6 \%(23)$ & $11.6 \%(23)$ & $p=0.777$ \\
\hline Homicide & & $<1.7 \%(<4)$ & $<1.4 \%(<4)$ & \\
\hline $\begin{array}{l}\text { Suicide in } \\
\text { poisoning }\end{array}$ & luding drug-related & $4.2 \%(10)$ & $3.5 \%(10)$ & \\
\hline Unknown & & 7.1\% (18) & $2.8 \%(7)$ & $p=0.007^{*}$ \\
\hline
\end{tabular}




\begin{tabular}{|c|c|c|c|c|c|c|}
\hline & $2001-2002$ & & & 2011-2012 & & \\
\hline & Group 1 & Group 2 & & Group 3 & Group 4 & \\
\hline & $\begin{array}{l}\text { Drug users } \\
\text { receiving } \\
\text { treatment }\end{array}$ & $\begin{array}{l}\text { Drug users } \\
\text { not receiving } \\
\text { treatment }\end{array}$ & & $\begin{array}{l}\text { Drug users } \\
\text { receiving } \\
\text { treatment }\end{array}$ & $\begin{array}{l}\text { Drug users not } \\
\text { receiving } \\
\text { treatment }\end{array}$ & \\
\hline & & & $\begin{array}{l}p \\
\text { value }\end{array}$ & & & $\begin{array}{l}p \\
\text { value }\end{array}$ \\
\hline Number & 91 (37.9\%) & 149 (62.1\%) & & $88(31.0 \%)$ & 196 (69.0\%) & \\
\hline Antipsychotics & $15.4 \%(14)$ & $16.1 \%(24)$ & 0.882 & $21.6 \%(19)$ & $25.5 \%(50)$ & 0.291 \\
\hline Antidepressants & $14.3 \%(13)$ & $11.4 \%(17)$ & 0.513 & $25 \%(22)$ & $20.4 \%(40)$ & 0.296 \\
\hline Anti-epileptics & $8.8 \%(8)$ & $4.0 \%(6)$ & 0.127 & $10.2 \%(9)$ & $11.2 \%(22)$ & 0.384 \\
\hline Psychostimulants & - & - & - & $<4.5 \%(<4)$ & $3.6 \%(7)$ & 0.4 \\
\hline Benzodiazepines & $48.4 \%(44)$ & $38.3 \%(57)$ & 0.124 & $77.3 \%(68)$ & $61.7 \%(121)$ & $0.024 *$ \\
\hline Methadone & $74.7 \%(68)$ & $42.3 \%(63)$ & $0.000^{*}$ & $92.0 \%(81)$ & $61.7 \%(121)$ & $0.000 *$ \\
\hline Buprenorphine** & - & $<2.6 \%(<4)$ & 0.267 & $4.5 \%(4)$ & $<2 \%(<4)$ & $0.024 *$ \\
\hline Opioids & $28.6 \%(26)$ & $34.9 \%(52)$ & 0.31 & $10.2 \%(9)$ & $11.7 \%(25)$ & 0.367 \\
\hline Morphine & $31.9 \%(29)$ & $47.0 \%(70)$ & $0.021^{*}$ & $15.9 \%(14)$ & $18.4 \%(36)$ & 0.34 \\
\hline Cannabis & $\begin{array}{l}33.0 \% \\
(30 / 91)\end{array}$ & $\begin{array}{l}26.8 \% \\
(40 / 149)\end{array}$ & 0.311 & $36.4 \%(32)$ & $36.2 \%(71)$ & 0.4 \\
\hline Cocaine & $8.8 \%(8)$ & $10.1 \%(15)$ & 0.745 & $12.5 \%(11)$ & $17.3 \%(34)$ & 0.218 \\
\hline MDMA & - & - & & - & $2.0 \%(4)$ & 0.158 \\
\hline Amphetamine & $<4.4 \%(<4)$ & $<2.6 \%(<4)$ & 0.591 & $8.0 \%(7)$ & $11.2 \%(22)$ & 0.269 \\
\hline
\end{tabular}

Non-prescribed medication in the two observation periods according to treatment status

\begin{tabular}{lllllll}
\hline Antipsychotics & $11.0 \%(8)$ & $6.0 \%(9)$ & 0.952 & $11.4 \%(10)$ & $12.5 \%(24)$ & 0.787 \\
Antidepressants & $8.8 \%(8)$ & $6.0 \%(9)$ & 0.42 & $6.8 \%(6)$ & $8.9 \%(17 / 192)$ & 0.565 \\
Anti-epileptics & $5.5 \%(5)$ & $2.7 \%(4)$ & 0.266 & $5.7 \%(5)$ & $7.8 \%(15)$ & 0.52 \\
Psychostimulants & - & - & & $<4.5 \%(<4)$ & $<2.0 \%(<4)$ & 0.622 \\
Benzodiazepines & $19.8 \%(18)$ & $14.8 \%(22)$ & 0.312 & $33 \%(29)$ & $35.9 \%(69)$ & 0.627 \\
Methadone & $26.4 \%(24)$ & $42.3 \%(63)$ & $0.013 *$ & $34.1 \%(30)$ & $63.0 \%(121)$ & $0.000^{*}$ \\
Buprenorphine** & - & $<2.7 \%(<4)$ & 0.267 & $<4.5 \%(<4)$ & $<2.0 \%(<4)$ & 0.059 \\
Opioids & $24.2 \%(22)$ & $28.9 \%(43)$ & 0.428 & $5.7 \%(5)$ & $8.3 \%(16)$ & 0.434
\end{tabular}




\begin{tabular}{|c|c|c|c|c|c|c|}
\hline Table 4: C & es of death & elation to $t$ & tment sta & in each obs & ation per & \\
\hline & $2001-2002$ & & & 2011-2012 & & \\
\hline & Group 1 & Group 2 & & Group 3 & Group 4 & \\
\hline & $\begin{array}{l}\text { Drug users } \\
\text { receiving } \\
\text { treatment }\end{array}$ & $\begin{array}{l}\text { Drug users } \\
\text { not receiving } \\
\text { treatment }\end{array}$ & & $\begin{array}{l}\text { Drug users } \\
\text { receiving } \\
\text { treatment }\end{array}$ & $\begin{array}{l}\text { Drug users } \\
\text { outside the } \\
\text { treatment }\end{array}$ & \\
\hline & & & $p$ value & & system & $p$ value \\
\hline Mean age & 40.4, SD: & 38.2 SD: & 0.068 & 44.7, SD: & 42.0, SD: & 0.056 \\
\hline & 8.524 & 9.486 & & 11.434 & 10.605 & \\
\hline Male & $78.0 \%$ & $88.6 \%$ & $0.028 *$ & $68.2 \%$ & $80.1 \%$ & $0.029 *$ \\
\hline & $(71 / 91)$ & $(132 / 149)$ & & $(60 / 88)$ & $(157 / 196)$ & \\
\hline Female & $22.0 \%$ & $11.4 \%$ & & $31.8 \%$ & $19.9 \%$ & \\
\hline & $(20 / 91)$ & $(17 / 149)$ & & $(28 / 88)$ & $(39 / 196)$ & \\
\hline Cause of de & & & Odds ratio & & & Odds ratio \\
\hline $\begin{array}{l}\text { Somatic } \\
\text { causes }\end{array}$ & 7.7\% (7/91) & $\begin{array}{l}12.8 \% \\
(19 / 149)\end{array}$ & $\begin{array}{l}0.57,95 \% \\
\text { CI: (0.23- } \\
1.42)\end{array}$ & $8.0 \%(7 / 88)$ & $\begin{array}{l}15.8 \% \\
(31 / 196)\end{array}$ & $\begin{array}{l}0.46,95 \% \\
\text { CI: (0.19- } \\
1.09)\end{array}$ \\
\hline Accidental & $78.0 \%$ & $66.4 \%$ & $1.793,95 \%$ & $83.0 \%$ & $67.9 \%$ & $2.305,95 \%$ \\
\hline poisonings & $(71 / 91)$ & (99/149) & $\begin{array}{l}\text { CI: (0.98- } \\
3.27)\end{array}$ & $(73 / 88)$ & $(133 / 196)$ & $\begin{array}{l}\text { CI: (1.23- } \\
4.33)^{*}\end{array}$ \\
\hline Trauma & $\begin{array}{l}11.0 \% \\
(10 / 91)\end{array}$ & $\begin{array}{l}10.7 \% \\
(16 / 149)\end{array}$ & $\begin{array}{l}1.026,95 \% \\
\text { CI: (0.44- } \\
2.37)\end{array}$ & $9.1 \%(8 / 88)$ & $\begin{array}{l}12.8 \% \\
(25 / 196)\end{array}$ & $\begin{array}{l}0.684,95 \% \\
(0.30-1.58)\end{array}$ \\
\hline Unknown & $\begin{array}{l}<4.4 \% \\
(<4 / 91)\end{array}$ & $\begin{array}{l}10.1 \% \\
(15 / 149)\end{array}$ & $\begin{array}{l}0.305,95 \% \\
\text { CI: } 0.09- \\
1.08)\end{array}$ & - & $\begin{array}{l}3.6 \% \\
(7 / 196)\end{array}$ & - \\
\hline
\end{tabular}

